\title{
Induction of B Cell-Activating Factor by Viral Infection Is a General Phenomenon, but the Types of Viruses and Mechanisms Depend on Cell Type
}

\author{
Marc Ittah $^{a}$ Corinne Miceli-Richard ${ }^{a}$ Pierre Lebon ${ }^{d}$ Coralie Pallier ${ }^{b}$ \\ Christine Lepajolec ${ }^{c}$ Xavier Mariette ${ }^{a}$ \\ aService de Rhumatologie, Institut National de la Santé et la Recherche Médicale (INSERM) U 1012, Hôpital Bicêtre,

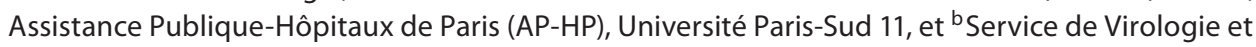 \\ 'Service de Oto-rhino-laryngologie, Hôpital Bicêtre, AP-HP, Le Kremlin-Bicêtre, et ${ }^{d}$ Service de Virologie, \\ Hôpital Cochin-Saint Vincent de Paul, AP-HP, Paris, France
}

\section{Key Words}

BAFF • Virus • Interferon • Autoimmunity $\cdot$ Innate immunity • Sjögren's syndrome

\begin{abstract}
B cell-activating factor of the TNF family (BAFF) plays a key role in promoting $B$ lymphocyte activation and survival. We previously showed in primary Sjögren's syndrome that salivary gland epithelial cells (SGECs), the resident targeted cells of autoimmunity in this disease, can produce BAFF after infection with a double-stranded RNA (dsRNA) virus by a protein kinase RNA (PKR)-dependent mechanism. This study aimed to assess the effect of different viruses on various cell types - SGECs but also dendritic cells (DCs) and monocytes - in the induction of BAFF. BAFF induction was observed after Sendai virus infection of monocytes and SGECs, as well as poly(l:C) stimulation of DCs. However, PKR inhibition by 2-aminopurine failed to reduce BAFF expression in these infected or stimulated cells. Conversely, in Sendai virus-infected monocytes, blocking type 1 interferon (IFN) receptor by anti-IFNAR1 antibody strongly inhibited BAFF expression. These results provide additional data suggesting that both dsRNA virus stimulation of DCs and single-stranded RNA virus infection of SGECs or monocytes can induce
\end{abstract}

BAFF expression, but through a PKR-independent mechanism for these 3 cell types and a type 1 IFN-dependent mechanism in monocytes and SGECs. Thus, BAFF induction by viral infection is a general phenomenon, but the types of viruses and mechanisms of the induction depend on the cell type.

Copyright $\odot 2010$ S. Karger AG, Basel

\section{Introduction}

B cell-activating factor of the TNF family (BAFF; also called BLyS) might explain autoimmune B cell activation in several systemic autoimmune diseases, including primary Sjögren's syndrome (pSS) [1], rheumatoid arthritis [2] and systemic lupus erythematosus (SLE) [3]. pSS is a prototype autoimmune disorder characterized by lymphocytic infiltration of salivary and lachrymal glands leading to xerostomia and xerophtalmia. This disease features both local and systemic autoimmune B cell activation mainly driven by BAFF. BAFF plays a crucial role in $B$ cell maturation, plasma cell survival, antibody response and immunoglobulin class switch recombination [4]. Interestingly, for not fully understood reasons, autoreactive B cells depend more on BAFF for survival than do allo-

\section{KARGER}

Fax +41613061234 E-Mail karger@karger.ch www.karger.com (c) 2010 S. Karger AG, Basel

$1662-811 X / 11 / 0032-0200 \$ 38.00 / 0$

Accessible online at:

www.karger.com/jin
Prof. Xavier Mariette

Service de Rhumatologie, Hôpital de Bicêtre

78 Rue du Général Leclerc

FR-94275 Le Kremlin-Bicêtre (France)

Tel. +33 14521 3758, Fax +33 14521 3757, E-Mail xavier.mariette@ bct.ap-hop-paris.fr 
reactive $B$ cells [5]. BAFF involvement in the pathogenesis of autoimmune diseases is well illustrated by BAFF overexpression in mice models, which leads to autoimmune disease mimicking SLE and pSS, as well as a two-fold increase in occurrence of B cell lymphoma [6]. In humans, an increased serum level of BAFF was reported in patients with rheumatoid arthritis, SLE and pSS, and was sometimes associated with the titer of autoantibodies [13]. The BAFF-secreting professional cells are monocytes, dendritic cells (DCs), macrophages and, to a lesser extent, granulocytes [7]. However, interestingly, in autoimmune diseases, BAFF can be secreted by resident cells in target organs of autoimmunity, such as salivary epithelial cells [8-10], synoviocytes [11] and astrocytes [12].

Increasing reports have suggested the involvement of innate immunity in autoimmune diseases. Interestingly, the key cytokine of innate immunity, type 1 interferon (IFN), has been shown to induce BAFF expression by both myeloid cells [7] and resident cells [5], which suggests that BAFF could be a bridge between innate immunity and autoimmune B cells. Recently, we demonstrated that stimulation or infection of salivary gland epithelial cells (SGECs), the main target of pSS, with poly(I:C) or reovirus, a double-stranded RNA (dsRNA) virus, induced BAFF expression and secretion by these resident cells through a mechanism depending on dsRNA-activated protein kinase RNA (PKR) [10].

In this study, we assessed the effect of different RNA viruses (single and double stranded) on BAFF secretion by different cell types (SEGCs as well as BAFF-secreting professional myeloid cells). We demonstrate that BAFF induction by viral infection is a general phenomenon, but the types of viruses and the mechanisms depend on the cell type.

\section{Materials and Methods}

\section{Cell Lines}

Human erythroleukemia K562 cells stably expressing BAFF were grown in RPMI supplemented with $10 \%$ fetal calf serum (FCS), penicillin $(100 \mathrm{IU} / \mathrm{ml})$ and streptomycin $(100 \mu \mathrm{g} / \mathrm{ml})$.

\section{Monocyte-Derived DC Culture}

Peripheral blood mononuclear cells (PBMCs) were isolated from peripheral blood by Ficoll-density gradient centrifugation. Monocytes were separated from peripheral blood mononuclear cells by use of immunomagnetic anti-CD14 beads according to the manufacturer's instructions (Miltenyi Biotech, Paris, France). DCs were differentiated from monocytes as described previously [13]. DCs and monocytes were derived from the same donors when the number of separated cells was sufficient (4 of 6 experiments). Briefly, isolated monocytes were incubated at $10^{6}$ cells $/ \mathrm{ml}$ in 75 $\mathrm{cm}^{2}$ flasks with RPMI-1640 medium (Invitrogen, Cergy Pontoise, France) supplemented with recombinant human granulocyte monocyte colony-stimulating factor at $50 \mathrm{ng} / \mathrm{ml}$ and interleukin (IL) -4 at $20 \mathrm{ng} / \mathrm{ml}$ (both from BD Bioscience, Le Pont de Claix, France) at $37^{\circ} \mathrm{C}$ in a humidified $5 \% \mathrm{CO}_{2}$ incubator. After 7 days, nonadherent immature monocyte-derived DCs were harvested and analyzed on flow cytometry. In total, $90 \%$ of cells showed typical DC morphology and expressed CD1a but not CD14 markers.

\section{SGEC Culture and Treatment}

Primary cultures of SGECs were established from minor salivary glands of 4 patients with pSS and 10 with sicca symptoms, as described [8]. Briefly, each lobule was cut into small fragments and set in six $75-\mathrm{cm}^{2}$ flasks with basal epithelial medium (a 3:1 mixture of Ham's F-12 and DMEM) supplemented with $2.5 \%$ FCS, epidermal growth factor $(10 \mathrm{ng} / \mathrm{ml})$, hydrocortisone $(0.4 \mu \mathrm{g} /$ $\mathrm{ml})$, insuline $(0.5 \mu \mathrm{g} / \mathrm{ml})$, penicillin $(100 \mathrm{IU} / \mathrm{ml})$ and streptomycin $(100 \mu \mathrm{g} / \mathrm{ml})$, and incubated at $37^{\circ} \mathrm{C}$ with $5 \% \mathrm{CO}_{2}$. After $4-5$ weeks of culture, cells at $70-80 \%$ confluence were dissociated with $0.125 \%$ trypsin-EDTA and recultured in 12-well plates coated with collagen type 1 .

\section{Anti-IFNAR1 Antibody and Virus Production}

The 64G12 monoclonal antibody, a mouse IgG1 that inhibits both the binding and biological activities of all human type 1 IFNs tested, was prepared by immunizing mice with a recombinant protein corresponding to the extracellular domain of the IFNAR1 chain, as described previously [14].

Stocks of the human strain reovirus-1 (Lang, a dsRNA virus) and Sendai virus (a single-stranded RNA, ssRNA, virus) were prepared from supernatants of infected Vero cells cultured in RPMI1640 with $2 \%$ FCS at a multiplicity of infection of 0.1 . At $72 \mathrm{~h}$ after infection, cells were frozen and thawed once.

\section{Monocyte, DC and SGEC Treatment}

Monocytes or DCs were stimulated with poly(I:C) $(30 \mu \mathrm{g} / \mathrm{ml})$ or infected with reovirus-1 or Sendai virus, at 0.01 plaque-forming units (PFU) per cell. To prevent PKR activation or type 1 IFN pathway induction, cells were treated with 2-aminopurine (2-AP; Sigma, Saint Quentin Fallavier, France; $5 \mathrm{~mm}$ for monocytes and $1 \mathrm{mM}$ for DCs, for $1 \mathrm{~h}$ at $37^{\circ} \mathrm{C}$, the dose chosen to avoid toxicity) or anti-IFNAR1 antibody $\left(50 \mu \mathrm{g} / \mathrm{ml}\right.$ for $30 \mathrm{~min}$ at $\left.37^{\circ} \mathrm{C}\right)$ before in vitro treatment. SGECs were infected by Sendai virus at $2 \times 10^{3}$ $\mathrm{PFU} / \mathrm{ml}$. All experiments were processed in duplicate.

\section{RNA Extraction and Real-Time Quantitative RT-PCR}

Total RNA was isolated from epithelial cells with use of the RNeasy Mini kit (Qiagen, Courtaboeuf, France) and digested with DNase I (Qiagen), according to the manufacturer's instructions. cDNA synthesis involved use of Enhanced Avian HS RTPCR (Sigma).

BAFF and $\beta$-actin cDNA levels were determined by use of light cycler-based kinetic quantitative PCR (Roche Diagnostics, Meylan, France). BAFF and $\beta$-actin PCR products were detected by use of LightCycler FastStart DNA Master SYBR Green I (Roche Diagnostics). To correct for variations in mRNA recovery and reverse-transcription yield, the amount of BAFF cDNA was normalized to that of $\beta$-actin. Results were expressed as increase in normalized values over that observed with untreated cells. Amplification involved the following primers: for BAFF, 5'-TGA- 


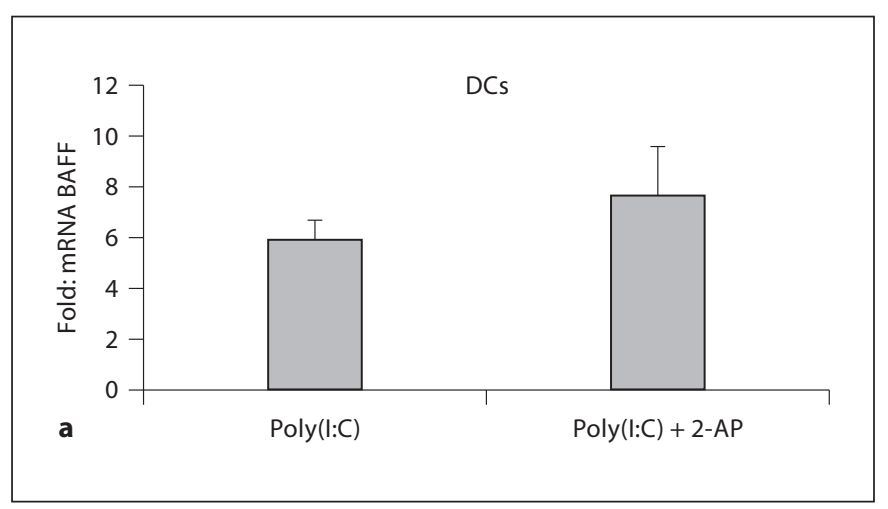

Fig. 1. BAFF expression in DCs does not depend on PKR. DCs were pretreated with 2-AP (1 $\mathrm{mM})$ before stimulation with poly(I:C) $(30 \mu \mathrm{g} / \mathrm{ml} ; 4$ experiments). a Expression of BAFF mRNA analyzed by quantitative real-time PCR $24 \mathrm{~h}$ after poly(I:C) stim-

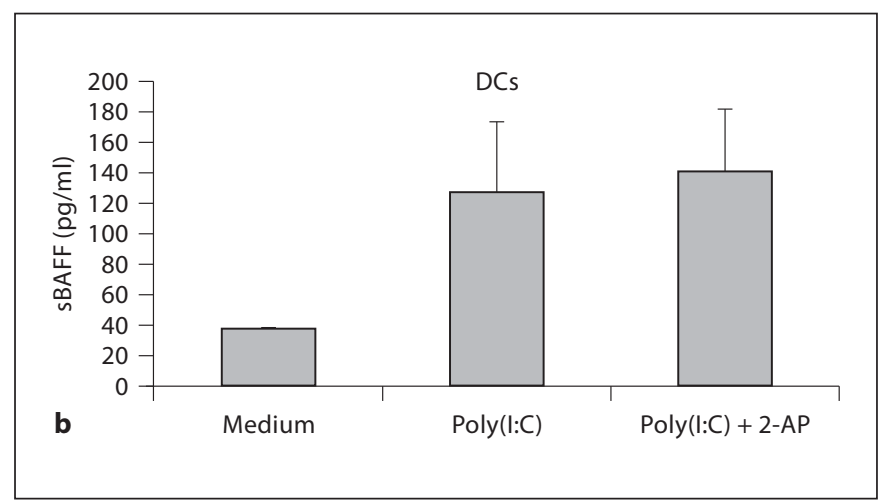

ulation with gene-specific primers (fold increase as compared with nonstimulated cells). b Secreted BAFF protein (sBAFF) analyzed by ELISA $48 \mathrm{~h}$ after poly(I:C) stimulation (detection limit = $2.43 \mathrm{pg} / \mathrm{ml})$. Results are means + SEM.
AACACCAACTATACAAAAAG-3' and 5'-TCAATTCATCCCCAAAGACAT-3'; for $\beta$-actin, $5^{\prime}$-GCTGTGCTACGTCGCCCT$3^{\prime}$ and $5^{\prime}$-AAGGTAGTTTCGTGGATGCC-3'. Primers for BAFF were specific to full-length BAFF, excluding any amplification of $\triangle B A F F$. Quantitative PCR runs were considered only if amplification efficiencies were high (slopes ranging from -3.2 to -3.8 ). Each sample was processed in duplicate, with initial incubation at $96^{\circ} \mathrm{C}$ for $10 \mathrm{~min}$, then $40 \mathrm{cycles}$ of $95^{\circ} \mathrm{C}$ for $10 \mathrm{~s}, 60^{\circ} \mathrm{C}$ for $15 \mathrm{~s}$ and $72^{\circ} \mathrm{C}$ for $20 \mathrm{~s}$. For each run, serially diluted cDNA of K562 cells for BAFF was used for quantitative standards. We determined the cell equivalence number of BAFF and $\beta$-actin mRNA in each sample according to the standard curve generated from values obtained with $\mathrm{K} 562$. The unit number showing relative BAFF mRNA level in each sample was determined as a value of BAFF cell equivalence normalized to that of $\beta$-actin. Melting curve analysis was performed to assess the specificity of PCR product. PKR cDNA levels were determined as previously described [15] with the amplification primers $5^{\prime}$-GTTTCAAAAGCAGTGTCACA-3' and 5'-CGATACATGAGCCCAGAACA-3'.

Detection and Quantification of Cytokine Secretion

BAFF level in the supernatants of cultures of unstimulated or stimulated SGECs, monocytes and DCs were determined by use of ELISA kits from R\&D systems (Lille, France). Active type 1 IFN levels were measured as previously described [16]. Supernatant samples underwent serial two-fold dilution in a 96-microwell plate, and active type 1 IFN content was determined by cytopathic effect reduction in vesicular stomatitis virus-infected MadinDarby bovine kidney cells. IFN titers were expressed as international units per milliliter.

\section{Statistical Analysis}

Results are shown as means \pm SEM. Wilcoxon signed-rank test was used for comparing 2 related samples or repeated measurements on a single sample. Statistical comparisons involved use of StatView, version 5.0 (SAS Institute, Cary, N.C., USA). p < 0.05 was considered significant.

\section{Results}

\section{BAFF Induction by Poly(I:C)-Stimulated DCs Does Not Depend on PKR}

Since poly(I:C) (a synthetic dsRNA) can induce BAFF expression by DCs, we assessed whether BAFF induction in poly(I:C)-stimulated DCs, like in poly(I:C)-stimulated SEGCs, depends on PKR [10]. As expected, poly(I:C) upregulated both BAFF mRNA and protein levels in DCs, with a 3-fold increase in BAFF secretion; however, PKR inhibition by 2-AP had no effect on BAFF expression and secretion in DCs (fig. 1), which suggests that the mechanism leading to BAFF expression by DCs differs from that in SGECs. Thus, the same stimulus of innate immunity can activate BAFF in different cells though different mechanisms.

\section{Sendai Virus but Not Reovirus-1 or Poly(I:C) Induces \\ BAFF Expression by Monocytes}

Since it is difficult to dissect the mechanism of action of poly(I:C) in DCs owing to the low number of cells, we tested blood monocytes for the effect of poly(I:C) or dsRNA viruses on BAFF expression. In monocytes, reovirus-1 (a dsRNA virus) had a slight effect on BAFF mRNA level (3-fold increase; fig. 2a) but no action on BAFF protein secretion (fig. 2c), as compared with SGECs in which reovirus-1 induced both BAFF mRNA and protein expression (fig. 2b, d). Poly(I:C) had no effect on BAFF expression by monocytes, both at mRNA and protein levels (fig. 2a, c). 
Fig. 2. BAFF expression is not induced in monocytes infected with reovirus-1 or stimulated with poly(I:C). a mRNA expression of BAFF was analyzed by quantitative real-time PCR $24 \mathrm{~h}$ after treatment with poly(I:C) $(30 \mu \mathrm{g} / \mathrm{ml})$ or reovirus-1 (0.01 PFU/cell) (fold increase as compared with noninfected cells) ( $\mathrm{n}=6$ experiments). c Secreted BAFF protein (sBAFF) analyzed by ELISA $48 \mathrm{~h}$ after treatment with poly(I:C) or reovirus-1. b, d Positive control with SGECs: both BAFF mRNA (b) and sBAFF protein (d) are induced by reovirus infection. Results are means + SEM.

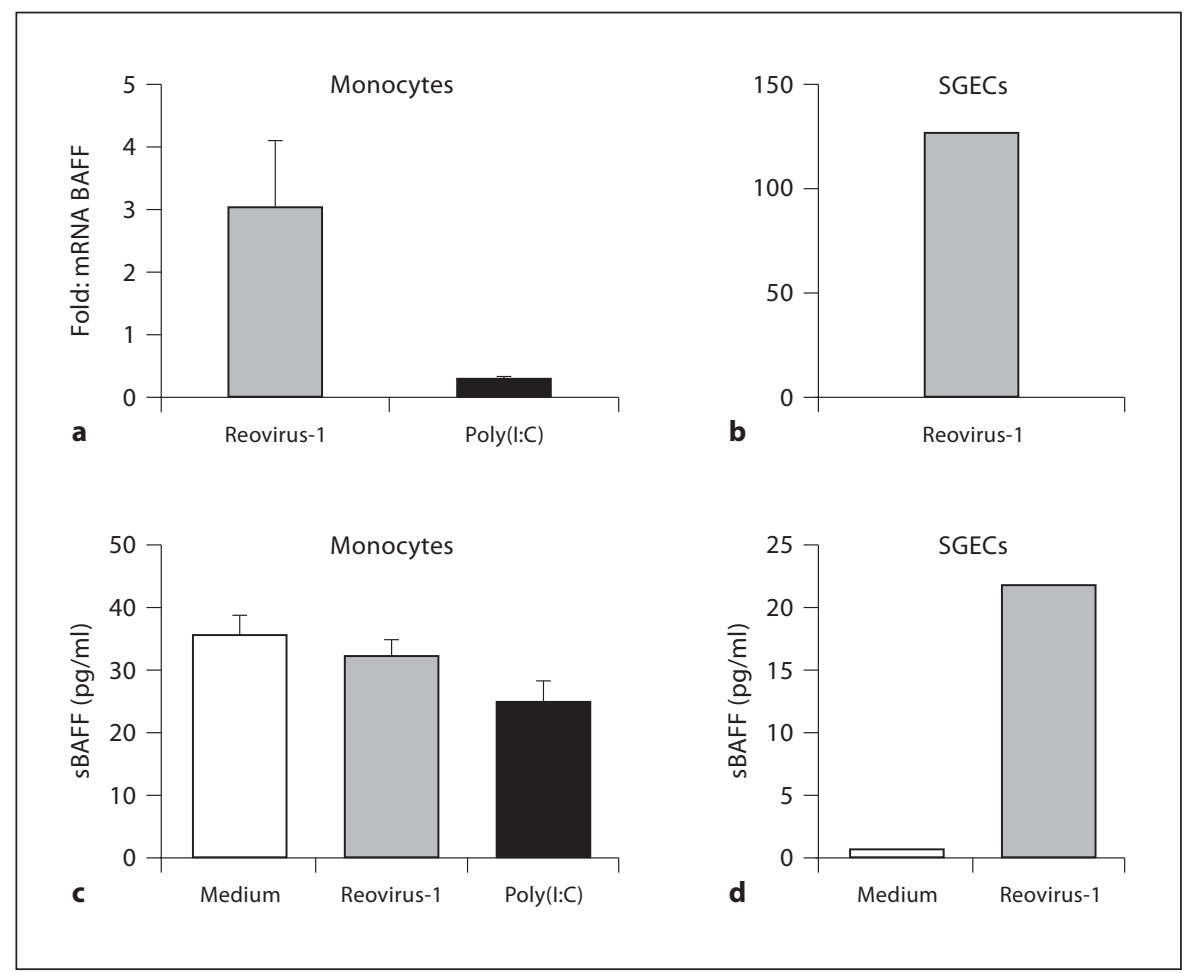

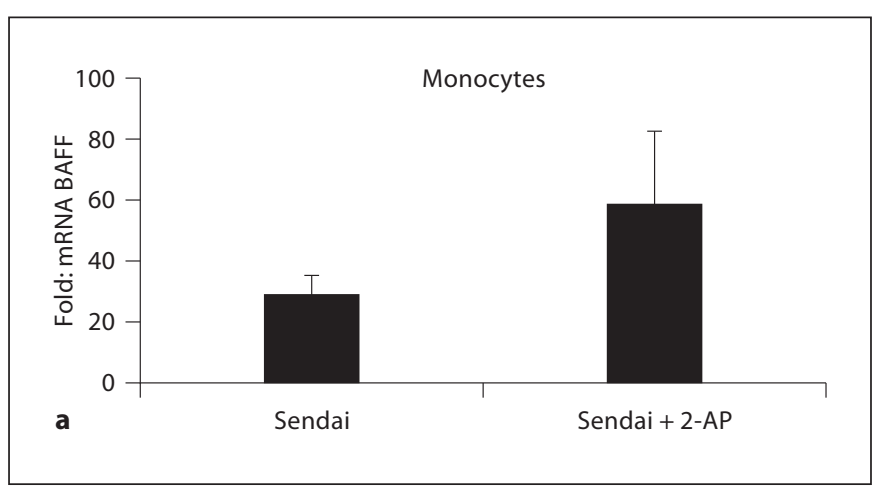

Fig. 3. BAFF induction in monocytes after Sendai virus infection does not depend on PKR. Monocytes were pretreated with 2-AP ( $5 \mathrm{mM})$ before infection with Sendai virus (0.01 PFU/ml; 4 experiments). a Expression of BAFF mRNA analyzed by quantitative

We observed a high basal level of BAFF secretion in monocytes as compared with SGECs, an observation in accordance with the fact that monocytes are the professional BAFF-producing cells. We then assessed the effect of another type of virus, Sendai virus, an ssRNA virus, on BAFF expression by monocytes. Sendai virus induced high BAFF expression and secretion. However, PKR in-

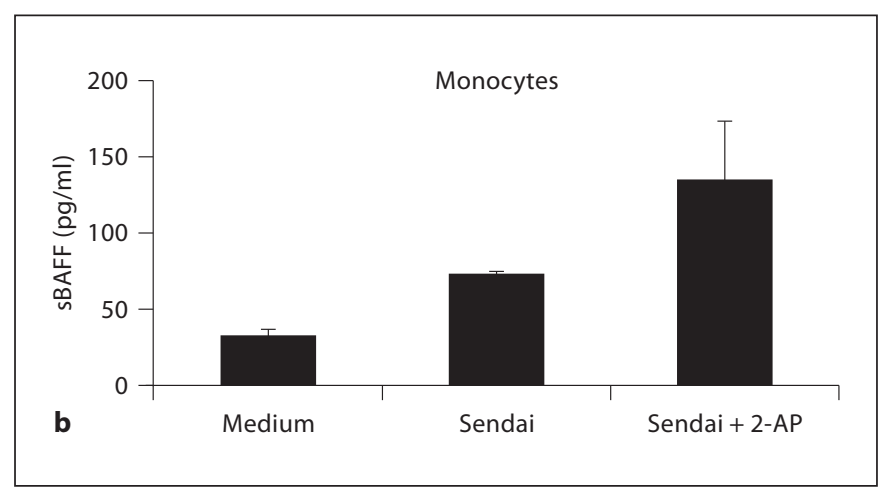

real-time PCR $24 \mathrm{~h}$ after Sendai infection (fold increase as compared with nonstimulated cells). b Secreted BAFF protein (sBAFF) analyzed by ELISA $48 \mathrm{~h}$ after Sendai infection (detection limit = $2.43 \mathrm{pg} / \mathrm{ml})$. Results are means + SEM.

hibition by 2-AP had no effect on BAFF induction either at the mRNA or at the protein level $(p=0.25$ and $p=0.62$, respectively; fig. 3).

Thus, BAFF expression induction by Sendai virus in monocytes might totally depend on induction of type 1 IFN by the virus. Interestingly, type 1 IFN was detected in the supernatant of monocytes only after stimulation with 

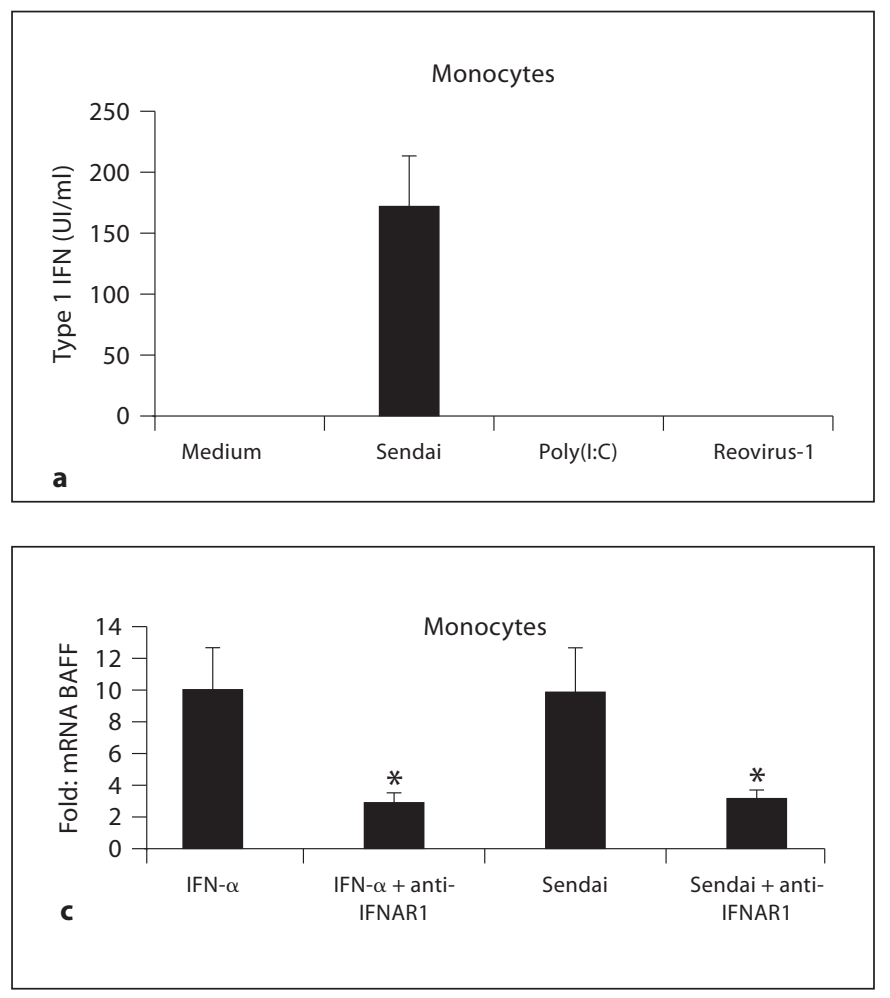

Fig. 4. BAFF induction after Sendai virus infection in monocytes depends on type 1 IFN. Sendai virus but not reovirus-1 or poly(I:C) induces type 1 IFN secretion by monocytes. a Supernatants of monocytes infected with Sendai virus $(0.01 \mathrm{PFU} / \mathrm{ml})$ or reovirus-1 (0.01 PFU/ml) or stimulated with poly(I:C) $(30 \mu \mathrm{g} / \mathrm{ml})$ were tested for active type 1 IFN secretion, as determined by cytopathic effect reduction in vesicular stomatitis virus-infected Madin-Darby bovine kidney cells. Results are means + SEM. $\mathbf{b}$ mRNA expression of PKR in monocytes $24 \mathrm{~h}$ after treatment with poly(I:C) $(30 \mu \mathrm{g} / \mathrm{ml})$, Sendai virus $(0.01 \mathrm{PFU} / \mathrm{ml})$ or reovirus-1 (0.01 PFU/cell) by quan-

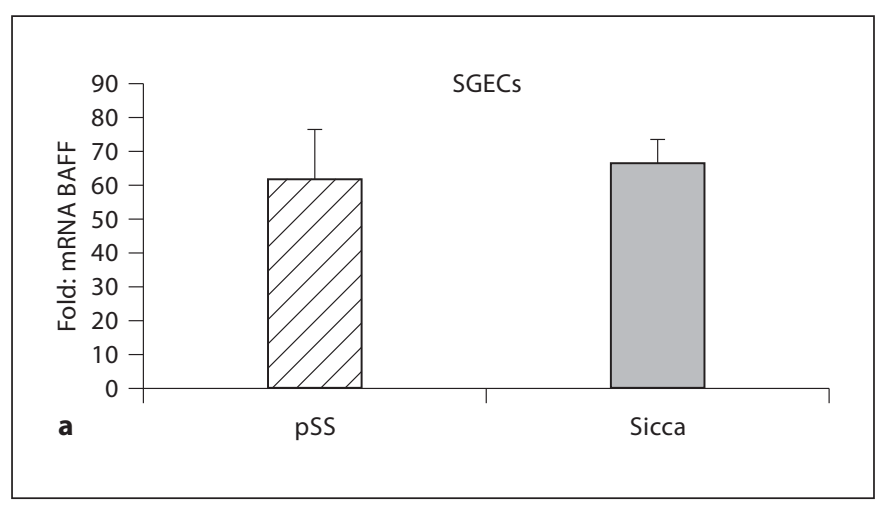

Fig. 5. Sendai virus induces BAFF expression by SGECs. SGECs were infected with Sendai virus $(0.01 \mathrm{PFU} / \mathrm{ml} ; \mathrm{n}=14$ experiments: cells from 4 pSS patients and 10 subjects with sicca symptoms only). Expression of BAFF mRNA analyzed by quantitative real-
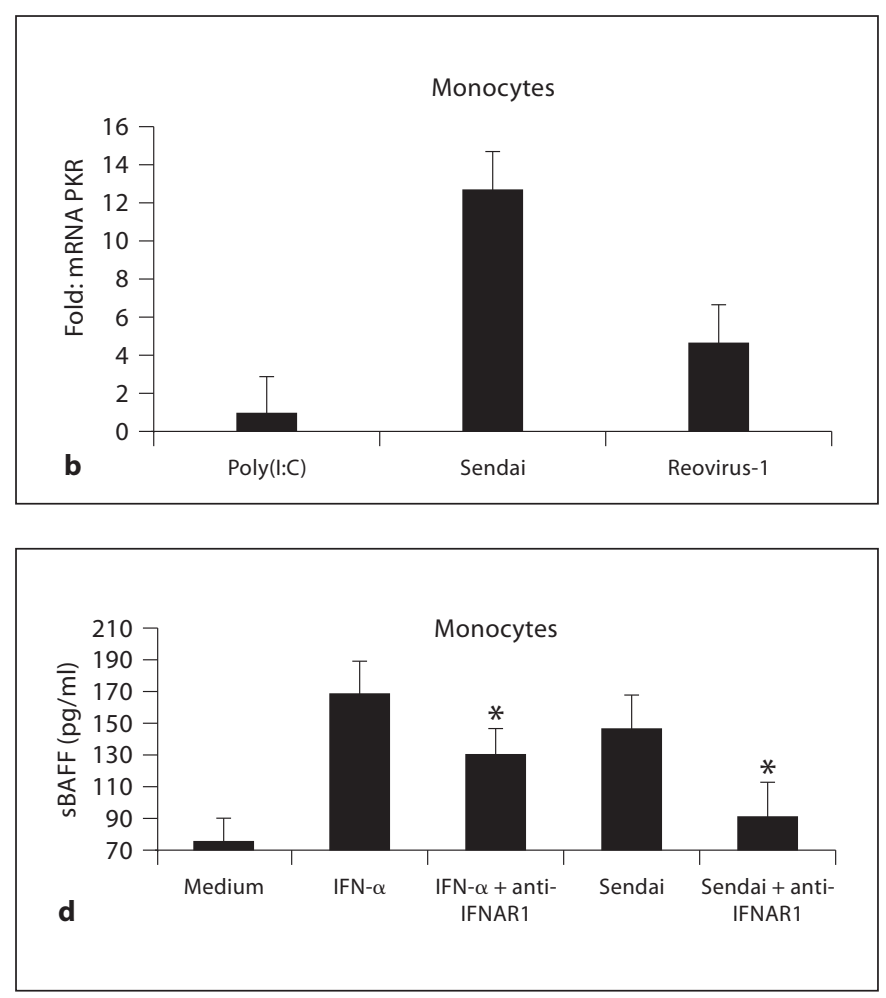

titative PCR (fold increase as compared with noninfected cells). Results are means + SEM. c, d Monocytes were pretreated with antiIFNAR1 antibody $(50 \mu \mathrm{g} / \mathrm{ml})$ before infection with Sendai virus $(0.01 \mathrm{PFU} / \mathrm{ml})$ or stimulation with IFN- $\alpha(2,400 \mathrm{UI} / \mathrm{ml} ; 6$ experiments). Results are means + SEM; ${ }^{*} p<0.05$ compared to cells treated with Sendai virus or IFN- $\alpha$ alone, Wilcoxon matched-pairs test. c mRNA expression of BAFF analyzed by quantitative realtime PCR $24 \mathrm{~h}$ after stimulation (fold increase as compared with nonstimulated cells). d Secreted BAFF protein (sBAFF) analyzed by ELISA $48 \mathrm{~h}$ after stimulation (detection limit $=2.43 \mathrm{pg} / \mathrm{ml}$ ). 


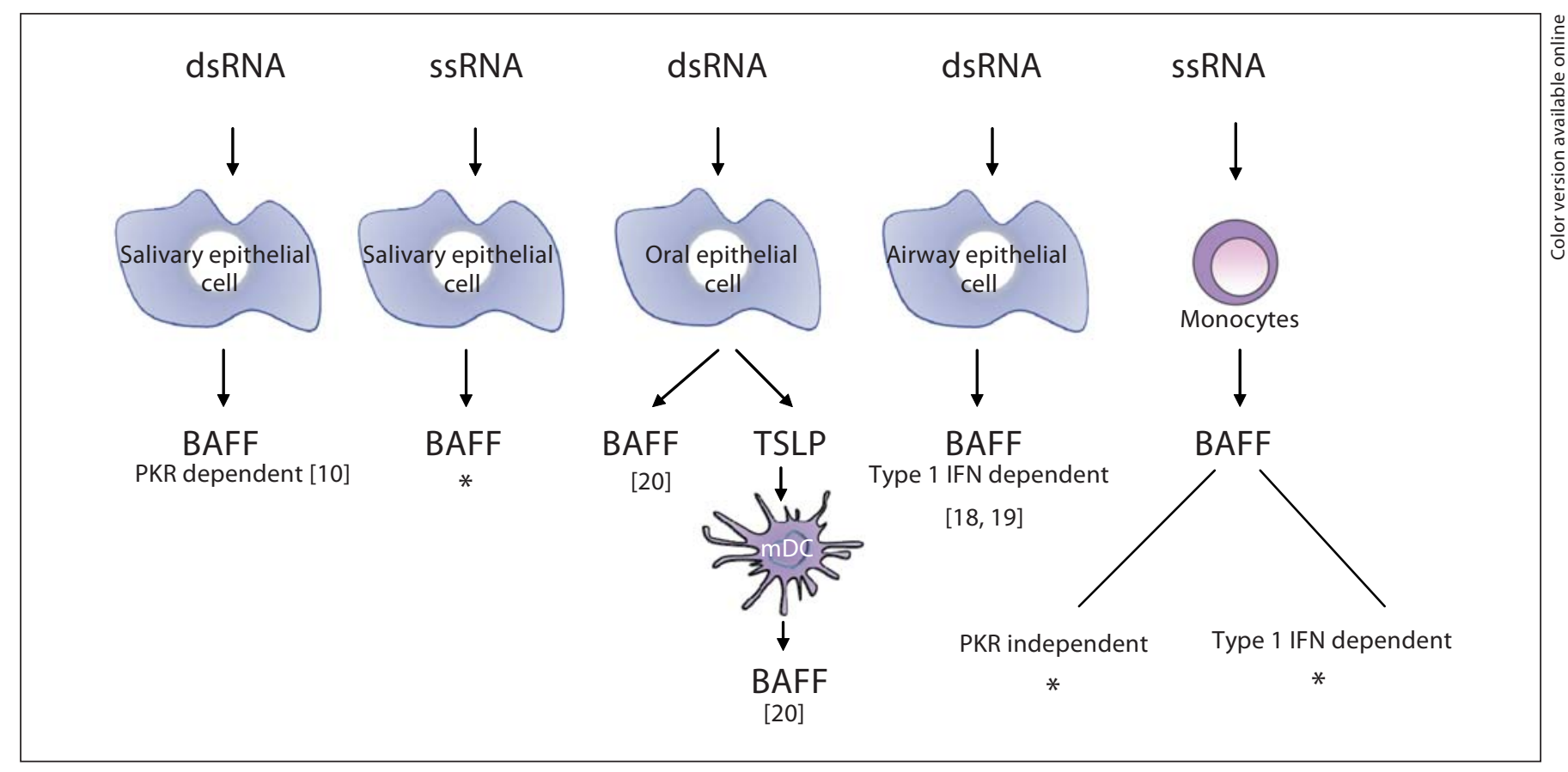

Fig. 6. Summary of BAFF induction, by RNA viruses, cell types and mechanism, if known. $\mathrm{mDC}=$ Monocytoid dendritic cell; TSLP = thymic stroma lymphopoietin. The asterisks show results from the present publication.

Sendai virus and not with poly(I:C) or reovirus, which do not induce BAFF in this cell type (fig. 4a). This finding was confirmed by the induction of PKR, mainly after Sendai virus infection (fig. $4 \mathrm{~b}$ ). $P K R$ gene is a well-known IFN-induced gene [17], and increased PKR mRNA expression reflected this type 1 IFN response to Sendai virus infection. Moreover, an anti-IFNAR1 monoclonal antibody inhibited BAFF induction after Sendai virus infection to the same extent as after IFN- $\alpha$ stimulation, which suggests that BAFF expression by Sendai virus-infected monocytes depends exclusively on type 1 IFN (fig. 4c, d).

\section{Sendai Virus Induces BAFF Expression by SGECs}

Because we previously exclusively studied the effect of dsRNA viruses on resident SGECs and because Sendai virus, an ssRNA virus, acts as a potent BAFF inducer by monocytes, we wondered whether Sendai virus could also induce BAFF expression by SGECs. As shown in figure 4, like reovirus-1 or poly(I:C), Sendai virus could induce both BAFF mRNA expression and protein secretion by SGECs, at a level comparable to that observed with dsRNA viruses, with no difference in SGECs derived from patients with pSS or with sicca symptoms only (fig. 5).

\section{Discussion}

In previous studies, we demonstrated that BAFF could be induced by SEGCs, the target cells of autoimmunity in pSS, after viral infection, but the mechanisms depended in part on TLR-3 and type 1 IFN and mainly on PKR [10]. Infection of airway epithelial cells by respiratory syncytial virus, another ssRNA virus, was able to induce BAFF expression during lower respiratory tract infection in infants [18]. Kato et al. [19] have reported that BAFF expression was induced by TLR3 ligand on human bronchial epithelial cells, both results emphasizing the central role of resident cells activated by innate immunity stimulation. In the present study, we show that BAFF induction by viral infection is a general phenomenon, but the types of viruses and mechanisms depend on cell type.

$\mathrm{Xu}$ et al. [20] showed that stimulation of DCs with poly(I:C) increased BAFF secretion, but the authors did not study the mechanism. Because PKR is involved in BAFF induction by SGECs, we hypothesized that the same mechanism could account for such BAFF induction in DCs. However, 2-AP inhibition of PKR had no inhibitory effect on BAFF expression in DCs. Because expanding DCs in vitro is difficult, we explored the mecha-

J Innate Immun 2011;3:200-207 
nism of action of poly(I:C) in monocytes, the other professional BAFF-secreting myeloid cell. However, neither poly(I:C) nor reovirus could induce BAFF expression in monocytes. This finding might be due to monocytes not expressing TLR3 [21]. Moreover, monocytes did not secrete type 1 IFN in response to poly(I:C) or dsRNA virus stimulation (fig. 4a), and PKR, a type 1 IFN-inducible gene, was not induced with poly(I:C) stimulation and only slightly induced with reovirus stimulation (fig. $4 \mathrm{~b}$ ).

Thus, we explored the action of another type of virus, Sendai virus, an ssRNA virus. Sendai virus was able to induce active type 1 IFN secretion by monocytes as well as PKR expression. We demonstrated for the first time that this virus could induce BAFF expression by monocytes. Interestingly, this BAFF induction did not involve a PKR-dependent pathway but, rather, was totally abolished by inhibition of type 1 IFN. Figure 6 summarizes the results concerning different viruses able to induce BAFF secretion in different cells and the involved mechanisms, when known. A type 1 IFN pathway is involved in most cases but may or may not be exclusive. The most important results issued from the present study regarding BAFF induction after Sendai virus infection of SGECs and monocytes are also included in figure 6.

This induction of BAFF by Sendai virus is relevant to local autoimmunity in pSS because epithelial cells were also able to express and secrete BAFF after this infection. Moreover, TLR7, the main receptor involved in ssRNA virus signaling is present in SGECs [9], and ssRNAs are also part of the immune complexes found in this autoimmune disease. As for BAFF induction by reovirus or poly(I:C), we found no difference in SGECs from patients with SS or with sicca symptoms only. Our culture was long term, and SGECs were infected after 4 weeks of in vitro culture, thereby avoiding the potential effect of the in vivo infiltrate and cytokine environment. Thus, SGEC expression of BAFF after viral infection is probably common in patients and healthy subjects. Nevertheless, the possibility of BAFF expression being higher in patients with pSS than in normal subjects requires further evaluation.

Altogether, our results show that the induction of BAFF after viral infection is not restricted to epithelial cells but also concerns professional BAFF-secreting myeloid cells. As in several other autoimmune diseases, in pSS, viral infection is suspected to be the first event in disease onset. However, to date, no particular virus has been clearly identified in this disease, but research is ongoing. The causal viruses could differ among individuals, depending on genetic predisposition and other factors. The fact that BAFF induction by viral infection is a general phenomenon but depends on the virus and cell type, and occurs though different mechanisms, may explain the diversity of diseases and phenotypes of diseases with a suspected link between innate immunity and BAFF induction.

\section{Acknowledgements}

We thank Pierre Eid, CNRS-UPR 9045, Villejuif, France, for providing anti-IFNAR antibody.

This study was supported by the Agence Nationale pour Recherche, Société Française de Rhumatologie.

\section{References}

-1 Mariette X, Roux S, Zhang J, Bengoufa D, Lavie F, Zhou T, Kimberly R: The level of BLyS (BAFF) correlates with the titre of autoantibodies in human Sjogren's syndrome. Ann Rheum Dis 2003;62:168-171.

2 Cheema GS, Roschke V, Hilbert DM, Stohl W: Elevated serum B lymphocyte stimulator levels in patients with systemic immunebased rheumatic diseases. Arthritis Rheum 2001;44:1313-1319.

3 Stohl W, Metyas S, Tan SM, Cheema GS, Oamar B, Xu D, Roschke V, Wu Y, Baker KP, Hilbert DM: B lymphocyte stimulator overexpression in patients with systemic lupus erythematosus: longitudinal observations. Arthritis Rheum 2003;48:3475-3486.

4 Litinskiy MB, Nardelli B, Hilbert DM, He B, Schaffer A, Casali P, Cerutti A: DCs induce CD40-independent immunoglobulin class switching through BLyS and APRIL. Nat Immunol 2002;3:822-829.

$\checkmark 5$ Mackay F, Browning JL: BAFF: a fundamental survival factor for B cells. Nat Rev Immunol 2002;2:465-475.

6 Mackay F, Woodcock SA, Lawton P, Ambrose C, Baetscher M, Schneider P, Tschopp J, Browning JL: Mice transgenic for BAFF develop lymphocytic disorders along with autoimmune manifestations. J Exp Med 1999; 190:1697-1710.

7 Nardelli B, Belvedere O, Roschke V, Moore PA, Olsen HS, Migone TS, Sosnovtseva S, Carrell JA, Feng P, Giri JG, Hilbert DM: Synthesis and release of B-lymphocyte stimulator from myeloid cells. Blood 2001;97:198204.

8 Ittah M, Miceli-Richard C, Eric Gottenberg J, Lavie F, Lazure T, Ba N, Sellam J, Lepajolec
C, Mariette X: B cell-activating factor of the tumor necrosis factor family (BAFF) is expressed under stimulation by interferon in salivary gland epithelial cells in primary Sjogren's syndrome. Arthritis Res Ther 2006; 8:R51.

9 Ittah M, Miceli-Richard C, Gottenberg JE, Sellam J, Eid P, Lebon P, Pallier C, Lepajolec C, Mariette X: Viruses induce high expression of BAFF by salivary gland epithelial cells through TLR- and type-I IFN-dependent and -independent pathways. Eur J Immunol 2008;38:1058-1064.

10 Ittah M, Miceli-Richard C, Gottenberg JE, Sellam J, Lepajolec C, Mariette X: B-cell-activating factor expressions in salivary epithelial cells after dsRNA virus infection depends on RNA-activated protein kinase activation. Eur J Immunol 2009;39:1271-1279.
Ittah/Miceli-Richard/Lebon/Pallier/ Lepajolec/Mariette 
-11 Ohata J, Zvaifler NJ, Nishio M, Boyle DL, Kalled SL, Carson DA, Kipps TJ: Fibroblastlike synoviocytes of mesenchymal origin express functional B cell-activating factor of the TNF family in response to proinflammatory cytokines. J Immunol 2005; 174:864870 .

12 Krumbholz M, Theil D, Derfuss T, Rosenwald A, Schrader F, Monoranu CM, Kalled SL, Hess DM, Serafini B, Aloisi F, Wekerle H, Hohlfeld R, Meinl E: BAFF is produced by astrocytes and up-regulated in multiple sclerosis lesions and primary central nervous system lymphoma. J Exp Med 2005;201:195200.

-13 Romani N, Reider D, Heuer M, Ebner S, Kampgen E, Eibl B, Niederwieser D, Schuler G: Generation of mature dendritic cells from human blood. An improved method with special regard to clinical applicability. J Immunol Methods 1996;196:137-151.

- 14 Eid P, Langer JA, Bailly G, Lejealle R, Guymarho J, Tovey MG: Localization of a receptor nonapeptide with a possible role in the binding of the type I interferons. Eur Cytokine Netw 2000;11:560-573.
5 Miceli-Richard C, Gestermann N, Ittah M, Comets E, Loiseau P, Puechal X, Hachulla E, Gottenberg JE, Lebon P, Becquemont L, Mariette X: The CGGGG insertion/deletion polymorphism of the IRF5 promoter is a strong risk factor for primary Sjogren's syndrome. Arthritis Rheum 2009;60:1991-1997.

16 Ankel H, Westra DF, Welling-Wester S, Lebon P: Induction of interferon- $\alpha$ by glycoprotein $\mathrm{D}$ of herpes simplex virus: a possible role of chemokine receptors. Virology 1998; 251:317-326.

17 Kirou KA, Lee C, George S, Louca K, Papagiannis IG, Peterson MG, Ly N, Woodward RN, Fry KE, Lau AY, Prentice JG, Wohlgemuth JG, Crow MK: Coordinate overexpression of interferon- $\alpha$-induced genes in systemiclupus erythematosus. Arthritis Rheum 2004;50:3958-3967.
8 Reed JL, Welliver TP, Sims GP, McKinney L, Velozo L, Avendano L, Hintz K, Luma J, Coyle AJ, Welliver RC Sr: Innate immune signals modulate antiviral and polyreactive antibody responses during severe respiratory syncytial virus infection. J Infect Dis 2009;199:1128-1138.

19 Kato A, Truong-Tran AQ, Scott AL, Matsumoto K, Schleimer RP: Airway epithelial cells produce B cell-activating factor of TNF family by an IFN- $\beta$-dependent mechanism. J Immunol 2006;177:7164-7172.

$20 \mathrm{Xu}$ W, He B, Chiu A, Chadburn A, Shan M, Buldys M, Ding A, Knowles DM, Santini PA, Cerutti A: Epithelial cells trigger frontline immunoglobulin class switching through a pathway regulated by the inhibitor SLPI. Nat Immunol 2007;8:294-303.

$>21$ Hornung V, Rothenfusser S, Britsch S, Krug A, Jahrsdorfer B, Giese T, Endres S, Hartmann G: Quantitative expression of Toll-like receptor 1-10 mRNA in cellular subsets of human peripheral blood mononuclear cells and sensitivity to $\mathrm{CpG}$ oligodeoxynucleotides. J Immunol 2002;168:4531-4537. 